Школьна Ольга Володимирівна, доктор мистецтвознавства, професор,

\title{
АКАДЕМІК ДВОХ АКАДЕМІЙ БОРИС ЛИСІН В СВІТЛІ УКРАЇНСЬКОЇ МАТЕРІАЛЬНОЇ КУЛЬТУРИ ТА КЕРАМОЛОГІЇ
}

Стаття присвячена життєвому і творчому иляху видатного украӥнського силікатознавия Бориса Савелійовича Лисіна. Ця людина сто років тому змінила хід розвитку галузі вітчизняної тонкої кераміки, очоливши пореволючійний всеукраӥнський трест "Фарфор-фаянс-скло». Дворянин за походженням, хіміктехнолог за освітою, знавецьь вітчизняних каолінів і глин за покликанням, останній куратор Києво-Межигірського художньо-керамічного інституту, переданого до відомства Украӥнського технологічного інституту - Інституту силікатів при КПI, Б. Лисін надзвичайно багато зробив для розвитку українського промислового мистецтвва і дизайну фарфору-фаянсу 1920-х - 1930-х рр., однак досі ия грань його спадщини повночінно не поцінована.

Ключові слова: Борис Лисін, украӥнський трест «Фарфор-фаянс-скло», 1920-mi-1930-ті рр., Межигір’я.

Статья посвящена жизненному и творческому пути выдающегося украинского силикатоведа Бориса Савельевича Лысина. Этот человек сто лет назад изменил ход развития отрасли отечественной тонкой керамики, возглавив послереволюичинный всеукраинский трест «Фарфор-фаянс-стекло». Дворянин по происхождению, химик-технолог по образованию, знаток отечественных каолинов и глин по призванию, последний куратор Киево-Межигоркого художественнокерамического института, переданного в ведомство Украинского технологического института - Института силикатов при КПИ, Б. Лысин чрезвычайно много сделал для развития украинского промышленного искусства и дизайна фарфора-фаянса 1920-х - 1930-х г2., однако до сих пор эта грань его наследия полноценно не оченена.

Ключевые слова: Борис Льсин, украинский трест «Фарфор-фаянс-стекло», 1920-ые - 1930-ые г2., Межигорье.

The article is devoted to a vital and creative way of the outstanding Ukrainian expert in silicates Boris Lysin. This person a hundred years ago changed process of domesticbranch thin ceramics, headed Ukrainian trust «Porcelain-faience-glass» after October revolution. A nobleman by origin, the chemist-technologist by education, the expert on domestic clay on calling, last curator Kievo-Mezhigirskogo art-ceramic institute, and the Ukrainian institute of technology - Institute of silicates at the Kiev polytechnical institute, B. Lysin has very much made for development of the Ukrainian industrial art and design of porcelain-faience 1920-1930th, however this side of its heritage is not estimated till now.

Keywords: Boris Lysin, Ukrainian trust «Porcelain-faience-glass», 1920-1930th, Mezhigirya. 


\section{АКАДЕМІК ДВОХ АКАДЕМІЙ БОРИС ЛИСІН В СВІТЛІ УКРАЇНСЬКОЇ МАТЕРІАЛЬНОЇ КУЛЬТУРИ ТА КЕРАМОЛОГЇ̈}

На сучасному етапі розвитку дизайну, фахівці з науки і техніки та знавці мистецтва мало контактують із знавцями вітчизняної художньої культури та мистецтвознавства. Між тим питання вивчення дизайну промислових виробів одночасно лежать у площині технічних знань та художніх, і потребують від фахівця широкої ерудиції. Прикладом багатошарового розуміння мистецтва фарфору-фаянсу та його інженернотехнологічних аспектів розвитку можна вважати творчість академіка двох академій НАН України Бориса Лисіна, плідна діяльність якого припала на першу половину XX ст.

Серед публікацій, присвячених Б. Лисіну, варто назвати праці вітчизняного історика науки і техніки В. Константинова [18-20], що намагався зібрати дайджест з історії життя і творчості вченого за архівом КНТУ «КПІ».

Шляхом аналізу останніх публікацій цього вченого у співавторстві з А. Колобовим у збірнику праць за матеріалами конференції в м. Іваново «Современное состояние, проблемы и перспективы энергетики и технологии в энергостроении» 1989 р., одноосібних у збірнику «Строительные материалы и конструкции» 1993 р. та у серії «Видатні українські вчені та інженери-будівельники» 2002 р., невирішеними лишилися питання зв’язку діяльності Б. С. Лисіна із «Укрфарфорфаянстрестом» 1920-х - 1930-х рр., а також ролі вченого в українському мистецтвознавстві, адже його праця 1930-х рр. напряму була пов'язана із осередком бойчукістів на Київщині - Межигірським художньо-керамічним інститутом.

Mета статті - представити житєвий і творчий шлях Бориса Лисіна в світлі української матеріальної культури, силікатознавства та керамології першої половини ХХ ст.

Борис Савелійович Лисін народився 22 липня за старим стилем 1883 р. у селищі Звягелі (нині м. Новоград-Волинську Жит. обл.) в родині начальника поштовотелеграфної контори Савелія Никаноровича Лисіна, українця, дворянина, надвірного радника. Його мати та старший брат Степан також працювали у поштово-телеграфній конторі. Мати була телеграфісткою 5-го розряду, а брат допомагав вести догляд за комунікаціями радіотелеграфу. Допомогаючи батькам, юний Борис доставляв кореспонденцію на заводи Волині як кур'єр.

Родина була багатодітною, проте більшість братів і сестер Бориса померли у молодому віці. Борис Савелійович отримав основи знань устінах Новоград-Волинського міського початкового чоловічого училища, а потім вступив до реального училища в Рівному, після якого можна було вступати до технічних вузів Російської імперії. Батько у цей час обіймав посаду міського голови Звягеля, проте коштів не вистачало. Тому Борис одночасно із навчанням давав приватні уроки рівненським школярам.

Найбільші старовинні підприємства з виготовлення елітарної керамічної продукції України, а також родовища глин, каолінів, креміню, вогнетривів тощо були зосереджені саме в цьому регіоні. В роки юнацтва Б. С. Лисіна на більшості з підприємств йшла реконструкція, встановлювалося нове обладнання і устаткування, механізувалися виробництва. Зокрема, на Баранівці, Городниці, Олевську, Токарівці, Кам’яному Броді, Довбиші тощо.

Маючи здібності та нахил до наукової праці, Б. С. Лисін цікавився технологічними процесами створення силікатів - від цементу й будівельної кераміки до скла, фаянсу та 
фарфору. Врешті перша робота вплинула на вибір подальшої професії і напрямок кар’єри. 1903 року Борис Савелійович закінчив Рівненське реальне училище (навчався з 1894 р.). Оскільки з п'ятого класу сам почав викладати тут же, по завершенні навчання продовжив викладацьку діяльність у реальному училищі Києва. До столиці переїхав з надією отримати вищу освіту в новоствореному Київському політехнічному інституті імені Імператора Олександра II.

1903 року в складі екзаменаційній комісії КПІ був сам Дмитро Іванович Мендєлєєв, який особисто перевіряв якість київської хіміко-технологічної освіти першого випуску ВУЗу (перші чотири факультети були відкриті 1898). У рік вступу Лисіна на базі КПІ саме започатковувалася перша хімічна лабораторія. Це давало можливість дослідним шляхом вивчати маси та поливи, того сирого матеріалу, який, за висловом Лисіна, «служит для проявления тех возвышенных стремлений человеческой души, кои вносят в жизнь восторг и красоту» [10, арк. 4].

Протягом 1903-1909 року Борис Савелійович Лисін - студент на хімічному відділенні ВУЗу. За виступи проти погромів 1905 року на шпальтах журналу «Студенческая мысль» деякий час перебував у тюремному ув’язненні. Проте, наявність активної громадянської позиції не вплинула на закінчення освіти. У 1908 році майбутній інженер-технолог проходив практику на Волині, про що лишив спогади. Він писав: «Працюючи в 1908 р. на Городницькому фарфоровому заводі авторові цих рядків доводилося спостерігати роботу «бразника» - головного робітника, що керував випалюванням. Протягом 48 годин він стежив за випалюванням від завантаження горна до припинення випалювання при температурі близько 1380 . Ця робота вимагала виняткової витривалості» [12].

Для дипломної роботи Борис Лисін обрав тему: «Полива для цегли з київської глини». Тобто, крім вивчення компонентів мас і полив силікатів Волині, вже устудентські роки коло наукових зацікавлень майбутнього видатного керамолога стосується всієї України. Радою професорів талановитого дипломанта обирають на посаду викладача курсу технології будівельних матеріалів, доручивши за сумісництвом посаду лаборанта.

1909 року Б. С. Лисін закінчив інститут і отримав звання інженера 1-го розряду. В тому ж році він розпочав працювати лаборантом, згодом асистентом і викладачем на кафедрі будівельних матеріалів, якою керував відомий вчений професор К. Г. Дементьєв. 31912 року Борис Савелійович очолив лабораторію випробувань будівельних матеріалів. Його самовіддана праця була гідно оцінена підвищенням по службі, й орденом Станіслава 3-го ступеню.

Вже за два роки по закінченню ВУЗу, молодий викладач Київської політехніки розпочинає активно друкуватися, видаючи іноді по кілька грунтовних наукових праць за рік. Вже 1911 р. вийшло друком кілька монографічних досліджень молодого науковця, що виступив у них вже як зрілий фахівець. Окремо заслуговує на увагу робота Б. С. Лисіна «Производство керамичееских изделий в Юго-Западной России» (з ретельним викладенням історії порцеляно-фаянсової промисловості України). Крім неї, значущою була низка наступних розробок з питань вивчення грунтів і мінеральних родовищ України. Вона мала надзвичайну вагу в сенсі практичних застосувань результатів досліджень. У галузі хімічного аналізу полив і мас, в першу чергу каолінів, 
Борис Савелійович провадив порівняльні досліди зазначених компонентів та їх застосування у зарубіжних країнах, вивчав закордонну і місцеву літературу, вводячи більшість з неї до наукового обігу України та Росії уперше.

Однією з найбільш ранніх праць визначного силікатознавця стала брошура «Керамиковыя канализационныя трубы. Производство и определение их технического достоинства» (К., 1916). Дане видання завдяки Б. С. Лисіну зберегло для нащадків не тільки технологію виготовлення означених виробів, а й зображення й креслення фігурних (або фасонних) різновидів димарів та ковпаків на димарі [21, с. 5], мистецтво виготовлення яких практично було втрачене протягом радянського часу. Ці реліквії за даними автора зберігалися при Київській міській управі, яка надала зразки труб і димарівковпаків для досліджень науковця [21. с. 4].

Протягом 1916-1917 років вчений обійняв свою першу керівну посаду -працював заступником директора, а згодом директором Київських піротехнічних майстерень при Київському політехнічному інституті. Дослідний шлях і проведення експериментів у лабораторії та майстернях уможливили різнобічне вивчення складних сполук i інгредієнтів, зокрема в галузі вогнетривких (піротехнічних) компонентів, які входили до складу кахлів для печей і камінів, метлаських підлог, вогнетривких різновидів цегли, а також шамоту, фаянсу, фарфору. У 1910-х роках молодий вчений був серед учасників 1-го Всеукраїнського з'їзду Наукових Робітників [3, арк. 22].

3'ясовуючи особливості вітчизняних каолінів та доводячи промислову цінність цієї сировини, Б. С. Лисін розробив унікальний метод збагачення каоліну, котрий пізніше був впроваджений на всіх каолінових підприємствах України та СРСР. Створивши власну «каолінологію», він виступає з науковими доповідями, розрахунками та раціоналізацією 3 приводу сировини глуховецького, просянівського, дубрівського, й особливо цеглицького родовищ на вітчизняних і закордонних хімічних конференціях, зокрема в Копенгагені, де його винайдення отримали міжнародний стандарт. Певною мірою Лисін, крім суто технології, вивчав ще й мистецькі властивості мас і полив.

У 1917 році Бориса Савелійовича обирають Головою Ради викладачів КПІ, висувають делегатом I-ої Всеросійської наради з реформи Вищої школи в Петербурзі (червень). 31917 року Б. С. Лисін став головою Ради викладацького корпусу інституту, делегатом Всеросійської наради з питань реформи вищої школи в Петрограді, членом комісії Української Академії Наук з вивчення природних ресурсів України, яку очолював академік В. І. Вернадський. Багато він зробив для опису і прогнозу промислової розробки глин та будівельних матеріалів на теренах України і півдня Росії.

Близько більшовицького перевороту вийшла ціла низка наукових праць і статей вченого у вітчизняних виданнях. Він вперше в українській науці знайшов «золотий перетин» хімії, силікатології, геології, архітектури, мистецтва і матеріальної культури, спираючись на міждисциплінарне вивчення абсолютно не досліджених ділянок науки. Як сутий відкривач, 1917 року Борис Савелійович погодився на чергову майже «авантюрну» науково-практичну і дослідницьку роботу в галузі цементів і в'яжучих речовин (алебастрів тощо.).

Після тотального розповсюдження в епоху модерну будівництва з цементом i бетоном, з'являється вітчизняне фундаментальне дослідження цього питання, яке 
вилилися у наукову працю, оприлюднену 1917 року «Изследование цементных строительных растворов, творенных на песке с искусственной и естесственной примесью глины». Наступні кілька років Лисін продовжував працювати над цією проблематикою.

Окремі розробки вченого торкалися питань вогнетривів, кислототривів, хімічного складу давньоруських розчину і плінфи. Серед наукових інтересів Бориса Савелійовича було створення новітньої методики впровадження «силікатології» в життя. Завдяки розробкам вченого, крім естетичних і практичних властивостей, наприкінці 1910-х у 1920-х роках почали надавати великого значення формам і технології виготовлення промислової кераміки - від найпростіших на перший погляд фасонів покрівельної дахівки, димарів до кубиків бруківки.

Окрему роботу означеній проблемі присвятив першим в Україні Б. С. Лисін. У виданні під назвою «Глини і глиняна промисловість на Україні. Черепиця, звончак для шляхів, фарфор, фаянс, цемент, шкло». (К., 1918) на 160 сторінках тексту вперше у вітчизняній керамічній промисловості висвітлювався весь спектр виготовлення «художніх силікатів», від іiі «нижчих» різновидів - тесаного каменю й «фемів» до вишуканого білого фарфору. Очевидно саме так варто розглядати вироби означеної галузі, зважаючи на взаємне збагачення технологічними здобутками й дотримуючись принципу ансамблевості. Ця робота була здійснена протягом часу, коли Борис Савелійович викладав неорганічну хімію у Київському будівельному технікумі, а технологію силікатів - у Народному університеті-політехнікумі (1917-1919рр.).

В Б. С. Лисіні уживався одночасно фізик і лірик. Так, Борис Савелійович мав поетичний хист, який неодноразово допомагав йому розкривати складні питання технології силікатів. 1918 року у вищезгаданій праці він писав: «Коли Фінляндію називають царством гранітів і озер, то Україну по справедливости можна величати країною каолінів і глин» [23. с. 5] або «Надаючи прикрасу нашим будівлям, кераміка без сумніву розвиває у нас любов та чуттє до краси, а це стремліннє в відшукованні прекрасного, мусить впливати користно на духовний розвиток народу» [23, с. 6]. Окремо в цій роботі було зроблене надзвичайно вагоме узагальнення по даним з історії виробництва цегли, дахівки й бруківки в Україні, яке актуальне до сьогодні.

Протягом 1918-1920 року вчений закінчив працю над темою «Про будівництво цегляного заводу з „сухим” та „мокрим” способом виробництва цегли» (рос. мовою) [16]. Розробляючи технологічні аспекти силікатів і в'яжучих розчинів для будівництва, Б. С. Лисін очолив окремий напрямок у становленні радянської промисловості. 1920 року його призначили керівником відбудови цементних заводів у Новоросійську. Експериментальна будівнича база дозволила вченому вивірити аналіз необхідних умов для будівництва і праці цементних заводів з боку вдосконалення технології.

1921 р. Борис Савелійович став завідувачем новоствореної кафедри технології силікатів, яка виникла на базі кафедри мінеральної технології та будівельних матеріалів КПІ, очолюваною перед тим вчителем Б. С. Лисіна професором К. Г. Дементьєвим. Цю почесну успадковану посаду майбутній академік буде з гордістю займати протягом 35 років (до 1956). 3 цього моменту Борис Лисін, у свої 38 років стає визнаним науковим авторитетом української і російської керамології, силікатології й певним чином мистецтво-й архітектурознавства. 
Протягом 1921-1922 рр. вже відомий на весь Радянський Союз хімік-технолог і силікатознавець Борис Савелійович Лисін викладав курс технології будівельних матеріалів у Київському архітектурному інституті. 31922 р. поєднав основну роботу професора і завідувача кафедри у КПІ із посадою декану хімічного факультету. Від 1923 р. збереглося фото Б. С. Лисіна у КПІ з рекламою локомобіля Державних Мальцовських заводів [3, 20]. Тобто у цей час, очевидно, науковець вивчав системи агрегатів і двигунів у керамічній промисловості. 31924 р. Борис Савелійович - викладач курсу технології будівельних матеріалів у Межигірському керамічному технікумі, потім в Українському технологічному інституті кераміки та скла. 31922 до 1927 pp. він постійно обирався членом Київської міської Ради, був делегатом IX Окружного з'їзду Рад.

За спогадами учнів, у 1920-х роках Борис Савелійович часто звертався до студентів з фразою: «Отдаёте ли Вы, молодой человек, себе отчёт, какую трудную специальность Вы выбираете? Вам придётся быть пионером» [20]. Можливо саме таке неповерхове і уважне ставлення до силікато- і керамології стало причиною, через яку, як відомо з флайєру 1927 року, виданого Межигірським керамічним інститутом, більшості з студентів Бориса Савелійовича було не просто здати екзамени й отримати кваліфікацію технолога або художника: випадкові люди у фарфоро-фаянсову і керамічну промисловість кінця 1920 - початку 1930-х років просто не потрапляли.

Викладання відомого професора у Межигір'ї уможливило після ліквідації інституції вберегти обладнання, частина якого за офіційною версією потрапила до факультету технології силікатів у КПІ, а друга опинилася в Одеському художньому інституті, спішно реформованому в училище. Саме ця технологічна база пізніше дозволила Михайлу Жуку, Жозефіні Діндо і Петру Мітковіцеру створити національну школу української порцеляни. Адже досвід викладачів-бойчукістів Межигірського технікуму Оксани Павленко, Івана Падалки, Василя Седляра i їx технологічні напрацювання були у повній мірі засвоєні одеситами.

Паралельно з 1922 по 1926 рік Борис Савелійович обіймав посаду офіційного консультанта Тресту «Фарфор - Фаянс - Скло». На замовлення тресту він як штатний технолог написав першу в Україні монографію рівня докторської дисертації «Виробництво фарфору й фаянсу» (1923 рік), після якої був призначений (19271930-ті рр.) директором Українського науково-дослідного інституту силікатної промисловості.

Монографія була наслідком ретельного опрацювання російських та іноземних друкованих джерел та власного «польового» та експериментального досвіду. Фактично, вона була підсумком десятилітніх наукових пошуків і лабораторних досліджень. У цій «синтетичній» праці Борис Савелійович не лише поєднав теоретичну, практичну та викладацьку базу, виклавши основи технології, що спиралися на реальні можливості праці в умовах вітчизняних заводів, а й розробив перспективи модернізації підприємств галузі з урахуванням мистецького напрямку розвитку виробництв.

Вже перший розділ монографії «Фарфор и фаянс, какрезультат достижений техники в области переработки глины», який складався із вступу з історії розвитку промислової і художньої кераміки світу, схеми поділу силікатів у своєму різноманітті на 8 основних 
категорій (класів), короткого начерку історії виникнення фарфоро-фаянсових заводів у Росії та в Україні й суто розділу з технології виготовлення фарфору, фаянсу, компонентів маси і полив, являв собою вичерпний довідково-енциклопедичний матеріал з повним описом каолінових та інших родовищ України по губерніях.

Цю працю Бориса Савелійовича Лисіна важко переоцінити. Адже досі на такій зрозумілій мові з послідовним і добре розтлумаченим викладенням не написано жодної праці з технології керамо- і силікатології. Лише перелік літератури складає більше трьохсот позицій по вітчизняних джерелах і сімдесят один по закордонних. Зокрема, Лисін спирається на дослідження Вауліна, технолога Абрамцево; Філіппова, фахівця 3 питань засвоєння технології ірізації і люстрів; автора першої монографії з історії виробництв фарфору-фаянсу Російської імперії і першого повноцінного марочника, Селіванова; фахівця з фотокераміки та фотографії на фарфорі Флека тощо.

Деякі суто мистецтвознавчі та статистичні дані цієї праці взагалі унікальні. Зокрема, автор наводить дати існування й описує основне устаткування двадцяти шести українських заводів порцеляни і фаянсу, тринадцятеро з яких припинили існування до більшовицького перевороту. Окремі позиції цього зведення в інших джерелах не зустрічаються, як, приміром, практично невідомий завод Смотрицького. Крім того, оскільки відсутні розвідки з етнографії фарфору, цікавими є спостереження, зафіксовані Борисом Савелійовичем щодо звичок населення Волині вшанування визначних майстрів порцеляни-фаянсу. Зокрема, Лисін свідчив: «Старожилы Волыни помнят времена, когда рабочим фарфоровых заводов оказывали почёт и остальные смертные должны были при встрече с ними отвешивать им низкий поклон» [22, с. 9].

Книжки Лисіна мали надзвичайний попит на виробництвах галузі в Україні. Нами зафіксовані документи в архіві Будянського фаянсового заводу, за якими технологи найбільшого післяреволюційного підприємства неодноразово зверталися до Правління тресту «Фарфор - Фаянс - Скло» (написання назви у різні роки змінювалось) із проханням закупити для них «Керамическую технологию» Б. С. Лисіна, оскільки ії на книжковому ринку Харкова не було. Так, у листі від 03.02.1925 р. правління заводу просить два екземпляри, оскільки видання потрібне для школи фабрично-заводського навчання. Крім того, серед паперів заводу зберігаються докази запрошення Бориса Савелійовича відвідати підприємство в якості члена журі [8].

По успішному виконанні всіх поставлених Трестом завдань, професор Лисін накопичив нові дані і знов видав фундаментальну працю. Оскільки у країні йшов процес стандартизації складників мас і полив для виробництва промислової кераміки, він запропонував власний варіант системи «ОСТів». На основі вивчення каолінових родовищ, він розробив систему перших вітчизняних стандартів на каолін, яка була затверджена Народним Комісаріатом важкої промисловості СРСР 1928 року. Цьогоріч вийшла друком і одна з відоміших його брошур «Каолин Глуховецкий».

Згодом за наполегливу працю в ім'я радянської керамології, вже як директор Українського науково-дослідного інституту силікатної промисловості, Борис Савелійович був «премійований» закордонними відрядженням. 3 метою вивчення каолінових виробництв Західної Свропи, задля просування вітчизняних каолінів на Захід, Б. С. Лисін вивчав це стратегічне для країни питання у творчих лабораторіях Німеччини, 


\section{АКАДЕМІК ДВОХ АКАДЕМІЙ БОРИС ЛИСІН В СВІТЛІ УКРАЇНСЬКОЇ МАТЕРІАЛЬНОЇ КУЛЬТУРИ ТА КЕРАМОЛОГІЇ}

Чехословаччини й Польщі. За даними автора, з 1921 по 1930 рік ним було надруковано 2 книги: «Керамика» та «Изучение каолинов» (по 30 друкованих аркушів кожна), 2 брошури та 12 статей [17].

Точний термін його перебування за кордоном невідомий, однак через кілька років він все ж таки отримав ступінь доктора технічних наук і професора (1936 рік). Практична і дослідна робота науковця постійно була пов'язана із науково-організаційною та педагогічною працею. Вчений очолював низку науково-дослідних інститутів, у тому числі працював директором представництва держтресту «Русские самоцветы» (Мінсировини в Україні). Під його керівництвом робились розрахунки найбільш проектування та модернізації потужних заводів сировини галузі, провадились реконструкції та будівництва підприємств з виготовлення силікатів і тонкої кераміки.

Борис Савелійович був членом Всесоюзного науково-технічного товариства силікатів, членом Українського відділення Радянського національного об'єднання істориків природознавства і техніки, а також багатьох наукових і науково-технічних товариств, зокрема «Знання». Його обирали редактором і членом редколегій визначних видань з історії техніки і силікатознавства, у тому числі «Вестник инженеров», «Керамика и стекло», «Стройматериалы», «Вестник технологии». У 1930-х роках Б. С. Лисін опублікував понад 20 книг, монографій і фундаментальних статей.

1939 року професору, доктору технічних наук Борису Савелійовичу Лисіну було присвоєне звання академіка Академії Наук України. Посвідчення та матеріали справи зберігаються нині в Інституті архівознавства Центральної наукової бібліотеки імені Вернадського в м. Києві, де створений окремий фонд Бориса Савелійовича Лисіна. Незавершені статті, відбитки надрукованих праць, креслення і світлини 1973 року до ЦНБ передала дружина академіка, його кохана однодумиця Марія Дмитрівна Лисіна. Із нею видатний керамолог виховав двох доньок, інженерів І. Б. та Н. Б. Лисіну. Їх можна побачити поруч із батьком на світлинах професорсько-викладацького складу хімікотехнологічного факультету випуску інженерно-технологічного факультету Київського Індустріального Інституту 1934-1939 років.

Згадані фото зберігаються в архіві Національного архіву українського гончарства Національного музею-заповіднику Українського гончарства в Опішному [1]. В цей час академік Лисін був завідувачем означеної кафедри. У цьому ж архіві зберігається диплом Доктора технічних наук Бориса Савелійовича Лисіна, виданий Вищою атестаційною комісією Всесоюзного Комітету у Справах Вищої школи СНК СРСР (без дати) [1, арк. 1] та атестат професора пр №001123, виданий у Москві 7 лютого 1946 року, у науковому званні якого Б. С. Лисіна затверджено по кафедрі силікатів протоколом №3 від 17 грудня 1936 року Рішенням Вищої Атестаційної Комісії (обидва за підписом заступника голови Вищої Атестаційної Комісії I. Ароскіна) [1, арк. 1зв.-2].

Цей же фонд, що складається із 28 документів, містить посвідчення Дійсного члена Академії Наук УРСР Бориса Савелійовича Лисіна, обраного 22 лютого 1939 року академіком (з фото і власноручним автографом), за підписом Президента Академії Наук УРСР академіка О. В. Палладіна [5. арк. 1-2]. Крім іншого, серед документів архіву зберігається посвідчення про затвердження від 19 серпня 1950 року Б. С. Лисіна Дійсним членом Академії Архітектури УРСР за підписом Президента Академії 
Архітектури УРСР В. Г. Заболотного [4, арк. 1-2]. Серед світлин фонду Опішного $є$ одна, де академік Борис Савелійович Лисін сфотографований з академіком Свгеном Оскаровичем Патоном [3, арк. 15].

Тут же в архівній справі НАУГ НМЗУГО кілька листів з фронту від сина Ігоря, адресованих до Татуся, Мамочки, Іринки та Ніночки (очевидно, сестер) за адресою: Київ-55, Політехнічний Інститут, буд. 4, кв. 42 [2]. 3 них випливає, що родина лишилася в окупованомуКиєві. Перший дослідник творчості Б. С. Лисіна, науковець В. О. Константинов наводить факт, що під час окупації Борис Савелійович задля виживання родини налагодив у домашніх умовах виробництво пудри, соди, мила, які його дочки обмінювали в селах на продукти [20, с. 53].

Але найбільш цікавим є підпис на світлині Бориса Савельйовича із зовнішністю а-ля Сальвадор Далі до улюбленої дружини, сповнений найніжніших почуттів: «Возлюбленной, Божественной, Незаменимой, Прекрасной как солнце юга, Очаровательной, как юношеский сон, Прелестной как поцелуй ребёнка, Восхитительной жене нашей Марусе на память от столь же Любвеобильного мужа Бориса Савельевича» [3, арк. 12]. Ця єдина сакраментальна фраза обожнювання доносить до нас всю поетичну емоційну схвильованість, душевні пориви видатного науковця, який до своєї честі ще й був далеко не черствою людиною-технарем.

Зайвий раз підтверджуючи тезу, що в кожному фізикові живе трошки лірика, варто зазначити, що перед самою Другою світовою академік Лисін очолив Інститут мінеральної сировини Академії Наук УРСР і відділення фізико-математичних наук. 1944 року, після звільнення Києва, очолив кафедру технології силікатів КПІ. 31945 Борис Савелійович почав розробляти науковий метод прискореного визначення якості бетонів та в'яжучих речовин. Винайшов ряд технологій новітнього цементу і в'яжучих речовин, присвятивши цій тематиці понад тридцять наукових робіт.

31945 по 1950 він - директор Інститут промисловості будматеріалів Академії будівництва й архітектури УРСР. Після обрання академіком ще й цієї Академії (1950 р.), Бориса Савелійовича за розробку безолов'яних і безсвинцевих емалей нагороджено Державною (Сталінською) премією СРСР (1950 р.). По завершенні Другої світової його наукові поради допомогли розробити технологію виготовлення ефективних та дешевих будівельних матеріалів для відбудови зруйнованих міст і сіл, віднайти нові ефективні види цементів.

1956 р. у зв'язку із погіршенням стану здоров'я Борис Савелійович вийшов на пенсію, проте продовжував роботу у вчених радах і комісіях Академії наук СРСР. Брав участь у роботі секції Держтехніки при Раді Міністрів УРСР. Крім вчених рад КПІ, Академії архітектури УРСР, входив до складу вчених рад Інституту промисловості будівельних матеріалів, Інституту чорної металургії, Інституту загальної і неорганічної хімії, Київського інженерно-будівельного інституту, Київського технологічного інституту скла, Технологічного інституту промисловості, Технічної ради Укрфарфорфаянсового об’єднання.

Вчений виховав цілу плеяду відомих вчених у галузі будівельних матеріалів і силікатів, стояв біля витоків створення в Україні Інституту колоїдних матеріалів, виховавши власну наукову школу. На основі дипломних проектів його студентів в Україні 


\section{АКАДЕМІК ДВОХ АКАДЕМІЙ БОРИС ЛИСІН В СВІТЛІ УКРӒ̈НСЬКОЇ МАТЕРІАЛЬНОЇ КУЛЬТУРИ ТА КЕРАМОЛОГІЇ}

збудовано низку цегельних, порцелянових заводів, проведена реконструкція каолінових і цементних підприємств. Загальна кількість вихованих ним студентів сягає чотирьох тисяч осіб. Тільки кандидатських дисертацій під його керівництвом було захищено близька тридцяти.

Протягом життя вчений написав майже 130 наукових праць, десяток з яких - вагомі монографії. Після виходу на пенсію, Б. С. Лисін намагався максимально викласти ще недрукований матеріал, який збирав впродовж довгих років. У фонді №28 ІА ЦНБУ зберігаються машинописи його рідкісних розробок в галузі кераміки. Серед них варто зазначити кілька. Зокрема, працю у співавторстві з Ю. С. Корніловичем (зятем) «Мікроструктура давніх київських будівельних розчинів» [11]; «Короткий нарис історії техніки силікатних виробництв на Україні» [12]; у співавторстві з К. В. Дажук і Б. І. Вишневським «Дослідження складу та властивостей кам'янокерамічних виробів 3 української сировини» (неопублікована стаття) [13]; «Краткий очерк возникновения и деятельности кафедры силикатов» [14]; «Изучение физико-химических свойств и структуры каолина новых месторождений Закарпатской области УССР» [15] та значна кількість інших розробок видатного без перебільшень вченого.

Борис Савелійович ніколи не був членом Комуністичної партії, хоча відзначався принциповістю і самовідданістю у праці. Помер академік Б. С. Лисін 22 листопада 1970 року, похований на Байковому кладовищі.

Висновки. Творчість непересічного силікатознавця Бориса Савелійовича Лисіна у своєму роді унікальна. Адже доробок вченого охоплює як пласти матеріальної культури, так і

\section{Jimepamypa}

1. Архів НАУГ НМЗУГО (Національний архів украйнського гончарства) Національного музею-заповідника украӥнського гончарства в с. Опішному). Ф. 18, оп. 1, спр. 1, арк. 1-2. Документи, світлини. 2. Архів НАУГ НМЗУГО. Ф. 18, оп. 1, спр. 2, арк. 6-8. Листи. 3. Архів НАУГ НМЗУГО. Ф. 18, оп. 2, спр. 2, арк. 12, 15, 20, 22. Світлини. 4. Архів НАУГ НМЗУГО. Ф. 18, оп. 2, спр. 4, арк. 1-2. Документи. 5. Архів НАУГ НМЗУГО. Ф. 18, оп. 2, спр. 5, арк. 1-2. Документи. 6. Вітренко В. В. [електронний ресурс]. - Режим доступу: http://novograd.org.ua/. Дата доступy: 08.10.2008 p. 7. Волков В. Химики: Биографический справочник / В. А. Волков, Е. В. Вонский, Г. Г. Кузнецова. - К. : Наукова думка, 1984. - С. 314. 8. ДАХО (Держсавний архів Харківського обл.). Ф.-Р. 1956, Український Трест фарфорфаянс-скло. оп. 1, д. 325. Приказы н / Треста. 10.101924 -01.11.1925. На 500 л. Л. 34, 35, 121. 9. История Академии наук Украинской СССР. - К. : Наукова думка, 1979. - С. 711. 10. Інститут архівознавства ЦНБУ імені В. Вернадського. Ф. 28, оп. 1, спр. 1. Окремі аркуші з друкованих пращь Б. С. Лисіна. Арк. 4. 11. ІА ЦНБУ. Ф. 28, оп. 1, спр. 30. 1955. 13 арк. Машинопис. На рос. та укр. мовах. 12. ІА ЦНБУ. Ф. 28, оп. 1, спр. 37. Не раніше 1963 р. 80 c. Короткий нарис історії техніки силікатних виробництв на Украӥні. Стаття. Машинопис з рукопис. вставками. На укр. мові. С. 8. 13. ІА ЦНБУ. Ф. 28, оп. 1, спр. 38. Б/д. Частина статті. Машинопис. На укр. мові. 14. ІА ЦНБУ. Ф. 28, оп. 1, спр. 39. Б/д. Частина статті. На рос. мові. 15. ІА ЦНБУ. Ф. 28, оп. 1, спр. 51. Б/д. Машинопис. Тези доповіді. На рос. мові.16. ІА ЦНБУ. Ф. 28, оп. 1, спр. 79. На 73 с. 3 автографом Б. С. Лисіна. 17. ІА 
ЦНБУ. Ф. 28, оn. 1, спр. 39. На 60 с. Краткий очерк возникновения и деятельности кафедры силикатов. Витримка. Б/д. Машинопис з рукописними правками. Арк. 10. 18. Колобов А. Деятельность академика АН УССР Б. С. Лысина в области технологии силикатов/ А. Колобов, B. Константинов // Современное состояние, проблемы и перспективы энергетики и технологии в энергостроении. Тезисы докладов Всесоюзной научно-технической конференции. - Иваново, 1989. - C.156-157. 19. Константинов В. Фундатор силикатной науки в Украине / В. Константинов // Строительныле материалы и конструкции. - 1993. - №2. С. 43. 20. Константинов В. Борис Савелійович Лисін (1883-1970) / В. Константинов // Видатні украӥнські вчені та інженери-будівельники. В.5 / гол. ред. М.М. Жербін; АБУ, ДНАББ імені В. Заболотного: Серія історичних нарисів. Ред. кол. : Г. А. Войцехівська та ін. - К. : Київоргбуд, 2002. - С. 50-57. 21. Лисин Б. Керамиковыя канализачионныя трубы. Производство и определение их технического достоинства. - К., 1916. - С. 4, 5. 22. Лисін Б. Виробництво фарфору й фаянсу. - К., 1923 рік. - С. 9. 23. Лисін Б. Глини і глиняна промисловість на Україні. Черепичя, звончак для шляхів, фарфор, фаянс, цемент, шкло».-К., 1918. - 160 с. 24. Особовий фонд Б.С. Лисіна // Інститут архівознавства Національної бібліотеки Украйни імені В. І. Вернадського. Ф. 28, оп. 1-2., спр. 1-294. 25. Особовий фонд Б. С. Лисіна // Національний архів украӥнського гончарства Національного музеюзаповіднику Українського гончарства в Опішному. Ф.18, оп. 1, спр.1-6; оп. 2, спр. 1-2. 